\title{
QUALITY OF LIFE OF ADULTS WITH CELIAC DISEASE
}

\author{
Alicja Kamińska ${ }^{1 A, C, D, E, F}$, Katarzyna Wojtas ${ }^{2 C, D, E, F}$, Ewelina Kaleta ${ }^{3 A, B, D, E, F}$
}

\begin{abstract}
'Laboratory of Theory and Fundamentals, Institute of Nursing and Midwifery, Faculty of Health Sciences, Jagiellonian University Medical College, Krakow, Poland

2Department of Clinical Nursing, Institute of Nursing and Midwifery, Faculty of Health Sciences, Jagiellonian University Medical College, Krakow, Poland

${ }^{3}$ ational Research Institute, Branch in Krakow, National Oncology Institute Maria SkłodowskaCurie, Poland
\end{abstract}

Authors' contribution:

A. Study design/planning • B. Data collection/entry • C. Data analysis/statistics $\bullet$ D. Data interpretation $\bullet$ E. Preparation of manuscript $\bullet$ F. Literature analysis/search $\bullet$ G. Funds collection

\author{
Address for correspondence: \\ Alicja Kamińska \\ Laboratory of Theory and Fundamentals \\ Institute of Nursing and Midwifery \\ Faculty of Health Sciences \\ Jagiellonian University Medical College \\ 12 Michałowskiego St., 31-126 Krakow, \\ Poland \\ e-mail: alicja.kaminska@uj.edu.pl \\ SUBMITTED: 20.07 .2020 \\ ACCEPTED: 06.09.2020 \\ DOl: https://doi.org/10.5114/ppiel.2020.103537
}

\begin{abstract}
Introduction: Celiac disease is a food intolerance leading to problems with digestion and absorption of nutrients. It modifies the assessment of quality of life, but its overall evaluation should include sociodemographic factors and received health treatment.

Aim of the study: To assess the quality of life of patients with celiac disease and to establish its determinants. Material and methods: A total of 165 adults with celiac disease participated in the study. The authors' questionnaire and the Gastrointestinal Quality of Life Index (GIQLI) questionnaire were used. Statistical analysis was performed using IBM SPSS Statistics 25, and the significance level was $p<0.05$.

Results: The respondents rated their quality of life in the social dimension the highest, and in the physical dimension the lowest. Age, marital status, and professional activity were not related to the overall assessment of the quality of life. This rating was higher in the group of men, residents of large cities, and people with higher education. The duration of celiac disease did not significantly affect the quality of life. Respondents without symptoms of the disease or with the occurrence of 1 or 2 of them assessed their quality of life better. Comorbidities significantly reduced quality of life. Respondents describing the support received from professionals as bad had lower quality of life in terms of physical and social functioning.

Conclusions: Treatment of celiac patients requires professionals providing care to implement interventions in order to improve patients' assessment of quality of life.

Key words: quality of life, celiac disease, chronic disease.
\end{abstract}

\section{INTRODUCTION}

Celiac disease is the most common food intolerance [1]. As a result of the toxic effects of gluten, a chronic inflammatory process of the small intestinal mucosa and intestinal villi atrophy are induced, and as a consequence impaired digestion and absorption of nutrients [2]. Most often it is diagnosed among people aged $30-50$ years [3]. The disease is characterised by abdominal pain, chronic diarrhoea, flatulence, constipation, nausea, vomiting, malnutrition, and weight loss in adults [2,4]. Other symptoms involve many systems and organs [2, 5-8]. People with diagnosed celiac disease more often suffer from comorbidities [9], including autoimmune endocrine diseases [10].

So far, the only effective method of treatment is a gluten-free diet [2], and the assessment of the effectiveness of nutritional treatment is based on the analysis of the diet and nutritional status of the patient [11]. Consumption of small amounts of gluten causes a relapse [2] and complications: neurological and mental [4], cardiovascular [6], urogenital system $[4,11]$, osteoarticular [11], hematopoietic [4, 12], gastrointestinal tract [6], and a reduction in the quality of life [13].

Celiac disease, as a chronic disease, modifies patients' perception of their quality of life, which, however, should not be assessed without taking into account sociodemographic, socio-living factors [14].

\section{AIM OF THE STUDY}

The aim of the study was to assess the quality of life of adult patients suffering from celiac disease and to establish the factors determining it.

\section{MATERIAL AND METHODS}

The method of diagnostic survey with the technique of a questionnaire form was used in the study. 
The research tools were the authors' questionnaire (28 questions about sociodemography and the course of the disease) and the Gastrointestinal Quality of Life Index (GIQLI) questionnaire, designed to assess the quality of life of adults with gastrointestinal diseases. The questionnaire contains 36 questions covering 5 aspects of quality of life: symptomatic dimension (19 questions), physical dimension (7 questions), emotional dimension (5 questions), social dimension (4 questions), and 1 question about the patient's well-being due to the limitations of the disease. The answers were presented on a 5-point Likert scale (range 0-4). The respondents could select only one answer. To obtain an overall Quality of Life Score, the results obtained in individual questions were summed. The range of points that could be obtained by the subject was from 0 to 144 . The higher the number of points, the better the quality of life [15].

The authors' tool was placed as a Google Form on the thematic forum of the Facebook social website called "Celiacy". After the pilot study, the question regarding the duration of illness was corrected. Pilot and proper studies were conducted on-line. Participants in the study were informed about the purpose of the study, voluntary participation, and maintaining full anonymity. The research was conducted in accordance with the principles of the Declaration of Helsinki.

Statistical analyses performed to verify research hypotheses were carried out using IBM SPSS Statistics 25 software. The Kolmogorov-Smirnov test, ShapiroWilk test, and nonparametric tests were used to evaluate the variables. Mann-Whitney and Kruskal-Wallis tests were used to verify the differences between the variables. In the performed statistical analysis, the level of significance was assumed at $p<0.05$.

\section{RESULTS}

In total 165 adults with celiac disease were qualified for the study. Most of them were women (94.5\%). The largest group were people aged $31-40$ years
(41.2\%). Residents of cities with over 150,000 inhabitants comprised $44.2 \%$ of respondents, $65.2 \%$ of all respondents had a university degree, and $80.0 \%$ were professionally active. Married persons constituted $62.4 \%$ of all respondents. The average age of respondents was 26.5 years with a deviation of 13.6 years. The subjects' age at the time of diagnosis ranged from 3 months to 59 years.

\section{Results of the GIQLI questionnaire}

The lowest value obtained in the Gastroenterological Quality Index by the respondents was 35 points, and the highest was 143 points; none of the subjects obtained the maximum number of points. The values obtained by the respondents in particular dimensions of quality of life are presented in Table 1.

The respondents rated their quality of life in the social dimension the highest - the average quality of life represented $16 \%$ of the maximum possible result in this dimension. The symptomatic dimension and well-being ( $15 \%$ of the maximum score) and emotional dimension ( $13 \%$ of the maximum score) were rated lower. The quality of life in the physical dimension was rated the lowest - the average quality of life accounted for $12 \%$ of the maximum possible score.

The quality of life of the respondents related to their well-being resulting from the limitations caused by the disease was 3.08 points (SD $=0.98$ points).

\section{The relationship between sociodemographic variables and the quality of life of the subjects}

The overall quality of life of the respondents was higher in the group of men $(p=0.0048)$. Moreover, men significantly less often felt limited by the treatment process $(p=0.045)$.

The age of the respondents did not affect the overall assessment of the quality of life. A statistically significant difference was found only in its physical dimension. The level of physical functioning was signifi-

Table 1. Measures of central tendency and dispersion of the results of the GIQLI questionnaire

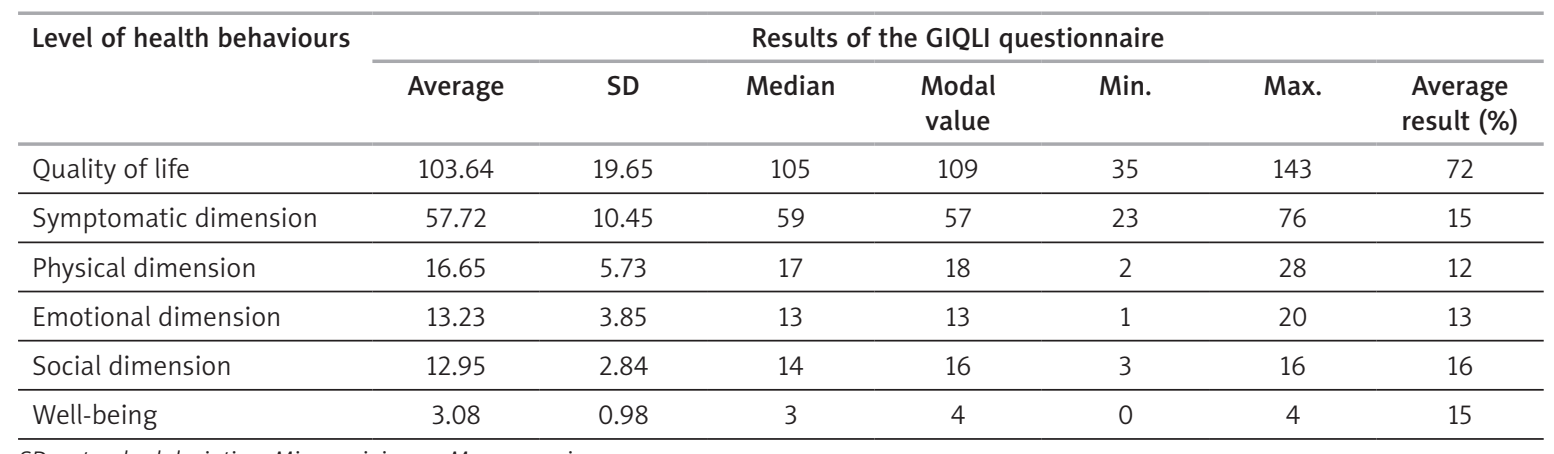

SD - standard deviation, Min. - minimum, Max. - maximum 
cantly lower in the group of people aged $51-60$ years ( $p=0.005)$.

The place of residence was significantly related to the assessment of the quality of life. Definitely better quality was found in people living in a city with over 150,000 inhabitants, compared to the respondents living in the countryside, both in terms of the overall quality of life $(p=0.005)$ and in the symptomatic $(p=0.025)$ and emotional $(p<0.001)$ dimensions.

Further analysis confirmed better quality of life only in the dimension of physical functioning in the group of the unmarried subjects $(p=0.034)$, while the worst functioning in this respect was characteristic for people with a spouse. The marital status of the respondents did not affect the overall assessment of the quality of life.

A higher assessment of the quality of life in the overall quality of life category was recorded among those with higher education $(p=0.036)$, and in the dimension of physical functioning among people with secondary education $(p=0.043)$. The analysis also showed that more points in the GIQLI questionnaire were obtained by those with higher and secondary education in the category assessing the sense of limitation caused by the treatment process $(p=0.034)$.

Analysis of the results did not show statistically significant differences between professional activity and the quality of life of the respondents.

\section{The relationship between variables connected with the health condition of the subjects and their quality of life}

Statistical analysis did not show that the duration of celiac disease significantly affected the quality of life of the respondents $(p>0.05)$.

Higher values in the assessment of quality of life were given by respondents who confirmed the $a b$ sence of disease symptoms or occurrence of 1 or 2 of them. Significant differences were noted in the overall assessment of quality of life $(p<0.001)$ and in particular dimensions: symptomatic $(p<0.001)$, physical $(p<0.001)$, emotional $(p=0.043)$, and social $(p=0.008)$. The results are presented in Table 2 .

Subjects who confirmed the presence of 2 or 3 comorbidities obtained lower scores in the GIQLI questionnaire. Differences in this area were noted in terms of the overall quality of life score $(p<0.001)$ and in the symptomatic $(p=0.005)$, physical $(p<0.001)$, and social $(p<0.001)$ dimensions, as well as in the category of feeling of limitations associated with the treatment process $(p=0.003)$.

In the study attention was also paid to the importance of support provided by the therapeutic team in assessing the quality of life by patients. A detailed analysis of the data confirmed the lower quality of life, in terms of physical $(p=0.041)$ and social

Table 2. Prevalence of celiac disease symptoms among subjects and quality of life

\begin{tabular}{|c|c|c|c|c|c|c|c|}
\hline \multicolumn{2}{|c|}{ Number of reported symptoms } & \multirow{2}{*}{$\begin{array}{c}\begin{array}{c}\text { Quality } \\
\text { of life }\end{array} \\
110.37\end{array}$} & \multirow{2}{*}{$\begin{array}{c}\begin{array}{c}\text { Symptomatic } \\
\text { dimension }\end{array} \\
61.41\end{array}$} & \multirow{2}{*}{$\begin{array}{c}\begin{array}{c}\text { Physical } \\
\text { dimension }\end{array} \\
18.41\end{array}$} & \multirow{2}{*}{$\begin{array}{c}\begin{array}{c}\text { Emotional } \\
\text { dimension }\end{array} \\
13.67\end{array}$} & \multirow{2}{*}{$\begin{array}{c}\begin{array}{c}\text { Social } \\
\text { dimension }\end{array} \\
13.74\end{array}$} & \multirow{2}{*}{$\begin{array}{c}\text { Well-being } \\
3.15\end{array}$} \\
\hline 0 & Average & & & & & & \\
\hline & $n$ & 27 & 27 & 27 & 27 & 27 & 27 \\
\hline & SD & 16.28 & 9.94 & 4.99 & 3.08 & 2.93 & 1.06 \\
\hline \multirow[t]{3}{*}{1} & Average & 116.82 & 63.45 & 20.18 & 15.36 & 14.18 & 3.64 \\
\hline & $n$ & 11 & 11 & 11 & 11 & 11 & 11 \\
\hline & SD & 12.84 & 7.31 & 4.47 & 2.42 & 2.04 & 0.50 \\
\hline \multirow[t]{3}{*}{2} & Average & 111.88 & 61.42 & 18.88 & 14.29 & 13.96 & 3.33 \\
\hline & $n$ & 24 & 24 & 24 & 24 & 24 & 24 \\
\hline & SD & 15.65 & 8.04 & 4.82 & 3.52 & 2.31 & 0,87 \\
\hline \multirow[t]{3}{*}{3} & Average & 105.63 & 58.80 & 17.29 & 13.56 & 12.80 & 3,17 \\
\hline & $n$ & 41 & 41 & 41 & 41 & 41 & 41 \\
\hline & SD & 17.41 & 8.74 & 5.64 & 3.81 & 2.58 & 0,83 \\
\hline \multirow[t]{3}{*}{4} & Average & 96.63 & 55.92 & 14.33 & 12.17 & 11.42 & 2,79 \\
\hline & $n$ & 24 & 24 & 24 & 24 & 24 & 24 \\
\hline & SD & 21.37 & 10.85 & 5.95 & 4.03 & 3.66 & 1,14 \\
\hline \multirow[t]{3}{*}{5} & Average & 92.13 & 51.08 & 13.76 & 11.95 & 12.53 & 2,82 \\
\hline & $n$ & 38 & 38 & 38 & 38 & 38 & 38 \\
\hline & SD & 20.38 & 11.26 & 5.50 & 4.39 & 2.52 & 1,04 \\
\hline Significance level $p$ & 0.000 & 0.000 & 0.000 & 0.043 & 0.008 & 0.071 & 0.53 \\
\hline
\end{tabular}

$n$-number of observations, SD - standard deviation, $p$ - significance level $p<0.05$ 
( $p=0.036)$ functioning, in patients who described the support they received from professionals as bad. The results are presented in Table 3.

\section{DISCUSSION}

Celiac disease is a chronic disease, associated with the occurrence of many restrictions, including dietary ones, and it requires systematic medical checks, also due to comorbidities.

Diagnosis of celiac disease can cause a feeling of loss or harm, which is manifested by experiencing anger, grief, and regret. A sense of helplessness or the need to deal with mental disorders such as depression are also familiar to patients [14]. Participants of the study conducted by Pietras-Mrozicka [16] declared experiencing stress in relation to food and a feeling of being misunderstood by others. They also emphasised that strict dietary recommendations induced changes of lifestyle, and that those changes may be described by patients as unwanted. In patients' opinion [17], spreading knowledge about gluten-free food can significantly improve their quality of life.

Assessment of the patients' health should also include a subjective assessment of their quality of life, due to the importance in the process of treatment and the patient-doctor relationship [14]. A holistic model of treatment and care for patients indicates the need to assess their quality of life and adapt the treatment process to the individual needs of patients.
The average number of points obtained by the respondents in the GIQLI questionnaire was 103.64. These values showed that the quality of life of the subjects with celiac disease was lower than in the healthy population, as point values in that group were 122.6 points [18]. The issue of the quality of life of people with celiac disease was also present in other studies.

In the authors' study, the quality of life was rated the highest in the social dimension, slightly lower values were given in the symptomatic, well-being, and emotional dimensions, while the lowest values were in the physical dimension. Therefore, fatigue, disability, malaise, and sleep disorders were significantly related to the reduction in the overall assessment of the quality of life of the respondents. For comparison, in the study of Brończyk-Puzon et al. [19], the quality of life of people who did not use a gluten-free diet as part of their treatment of celiac disease was higher in the psychological and social dimensions, as well as in general complacency with health. Casellas et al. [20] proved that in the study group the highest rated category of quality of life was that related to well-being resulting from the treatment process and social functioning. On the other hand, the emotional functioning dimension was rated the lowest.

In our own study, unequal representation of women and men was one of the limitations that may have distorted the results in the area of the relationship between gender and quality of life. Similarly, gender

Table 3. Support from medical staff and quality of life

\begin{tabular}{|c|c|c|c|c|c|c|c|}
\hline \multicolumn{2}{|c|}{ Number of reported symptoms } & \multirow{2}{*}{$\begin{array}{c}\text { Quality } \\
\text { of life }\end{array}$} & \multirow{2}{*}{$\begin{array}{c}\begin{array}{c}\text { Symptomatic } \\
\text { dimension }\end{array} \\
55.43\end{array}$} & \multirow{2}{*}{$\begin{array}{c}\begin{array}{c}\text { Physical } \\
\text { dimension }\end{array} \\
13.67\end{array}$} & \multirow{2}{*}{$\begin{array}{c}\begin{array}{c}\text { Emotional } \\
\text { dimension }\end{array} \\
11.48\end{array}$} & \multirow{2}{*}{$\begin{array}{c}\begin{array}{c}\text { Social } \\
\text { dimension }\end{array} \\
11.05\end{array}$} & \multirow{2}{*}{$\begin{array}{c}\text { Well-being } \\
2.52\end{array}$} \\
\hline Bad & Average & & & & & & \\
\hline & SD & 23.26 & 13.30 & 5.53 & 4.94 & 3.56 & 1.21 \\
\hline \multirow[t]{2}{*}{ Unsatisfactory } & Average & 102.91 & 57.56 & 16.38 & 13.26 & 12.68 & 3.03 \\
\hline & SD & 15.87 & 8.60 & 5.13 & 3.31 & 2.81 & 0.94 \\
\hline \multirow[t]{2}{*}{ Average } & Average & 101.94 & 55.98 & 16.60 & 12.90 & 13.33 & 3.13 \\
\hline & $n$ & 52 & 52 & 52 & 52 & 52 & 52 \\
\hline Good & SD & 17.70 & 9.42 & 5.36 & 3.65 & 2.57 & 0,86 \\
\hline \multirow[t]{3}{*}{ Very good } & Average & 106.78 & 58.67 & 17.06 & 14.11 & 13.56 & 3,39 \\
\hline & $n$ & 18 & 18 & 18 & 18 & 18 & 18 \\
\hline & SD & 16.94 & 10.01 & 4.77 & 3.10 & 2.31 & 0,70 \\
\hline Significance level $p$ & 0.000 & 0.063 & 0.264 & 0.041 & 0.188 & 0.036 & 0.105 \\
\hline
\end{tabular}

$n$-number of observation, SD - standard deviation, $p$ - significance level $p<0.05$ 
disproportions were present in the study conducted on-line by Golińska et al. [21].

The authors, like other researchers, analysed the factors determining the quality of life, such as age, gender, place of residence, education, marital status, and professional activity.

In the authors' study, the age of the respondents did not differ from the age of respondents who took part in other studies [3]. Whereas, women confirmed a reduced quality of life, especially in terms of wellbeing resulting from the treatment process. The place of residence in a large city and higher education had a significant relationship with a better assessment of the quality of life of the respondents. However, the relationship between marital status and professional activity was not confirmed. Lower quality of life in the group of women was also confirmed in studies conducted by Casellas et al. [20]. In comparison, in the study of Lee et al. [22] the relationship between gender and quality of life was not confirmed, but a significant relationship with age was demonstrated - the quality-of-life assessment was better among people over 65 years old. People with higher education rated their quality of life better. It was not confirmed that the place and region of residence had a significant relationship with the quality-of-life assessment. Studies among people with celiac disease were also undertaken by Alahmari et al. [23]. The published results did not confirm a significant relationship between the gender, age, education, marital status, and professional activity of the respondents and their quality of life. Zysk et al. [24] in their studies also did not show a relationship between the place of residence and the education of the participants and their quality of life. The quoted studies indicate differences in the area of the relationship between sociodemographic variables, which may result from cultural and regional differences between the studied populations.

The search for factors related to the quality of life of chronically ill people cannot ignore those related to the course of the disease. The analysis of the results of our own research did not show that the duration of celiac disease was significantly related to the quality of life of the subjects. However, such a relationship was demonstrated in the studies of Lee et al. [22] - the longer the disease lasted, the higher the quality-of-life rating was. The results confirming this relationship were obtained by Casellas et al. [20] and Alahmari et al. [23].

Our own research showed that the occurrence of more symptoms of the disease significantly reduced the quality of life of the respondents in general, as well as in most of its dimensions. Deepak et al. [25] published results indicating a reduced quality of life in patients with this diagnosis, which was also associated with a greater number of celiac symptoms. Casellas et al. [26] also showed a significant relation- ship between the occurrence of disease symptoms and a decrease in the quality of life of the subjects. The results of our own research also showed that the quality of life of people additionally diagnosed with other chronic diseases was significantly lower in the symptomatic, physical, and social dimensions and well-being related to the treatment process.

Providing social support by specialists may be of key importance for assessing the quality of life by patients [22], which was also proven by the analysis of our own research. Negative assessment of support was significantly related to the lower quality of life of the respondents in the physical and social dimensions. Perhaps, such a conclusion should cause the therapeutic team to reflect on the form and scope of support provided to patients. Unfortunately, scientific studies report negative opinions of celiac patients about health care. Limanowska et al. [27] published the conclusions of their study, which expressed dissatisfaction with the received health services, noting the incompetence of specialists. Ortega et al. [28] pointed out that the specificity of the disease necessitates constant medical care. Also, in the opinion of Gładyś et al. [29], people with celiac disease should have full access to a general practitioner, a gastroenterologist, a psychologist, and a dietitian, in order to constantly control the course of the disease, thus giving them a chance for full social activity and improving their quality of life.

The analysis of our own and other authors' research results draws attention to the need to conduct further studies among patients with celiac disease in order to determine the factors influencing the improvement of self-assessment of their quality of life.

\section{CONCLUSIONS}

Subjective assessment of the quality of life of people with celiac disease is an area of research that requires further exploration and sensitisation of care professionals to patients' problems.

Due to the wide spectrum of disease symptoms and their impact on the functioning of patients, interventions should be undertaken in the area of modifiable factors improving the quality of life of patients.

\section{Disclosure}

The authors declare no conflict of interest.

\section{References}

1. Andrzejewska M. Rys historyczny badań nad chorobą trzewną. Acta Medicorum Polonorum 2016; 6: 23-28.

2. Bubis E, Przetaczek-Rożnowska I. Gluten i choroby wynikające z jego nietolerancji. Kosmos 2016; 65: 293-302.

3. Myszkowska-Ryciak J, Harton A, Gajewska D. Analiza wartości odżywczej i kosztów diety bezglutenowej w porównaniu do standardowej racji pokarmowej. Medycyna Ogólna i Nauki o Zdrowiu 2015; 21: 312-316. 
4. Horvath A, Dziechciarz P. Celiakia - trudności w diagnozowaniu dorosłych. Medical Tribune 2015; 3: 64-66.

5. Cruz IT, Fraiz FC, Celli A, et al. Dental and oral manifestations of celiac disease. Med Oral Patol Oral Cir Bucal 2018; 23: $217-223$

6. Czerwińska D, Kołłajtis-Dołowy A, Trębska J. Częstotliwość spożycia wybranych bezglutenowych produktów zbożowych wśród osób chorych na celiakię. Problemy Higieny i Epidemiologii 2018; 99: 58-63.

7. Urban-Kowalczyk M. Objawy zaburzeń psychicznych w celiakii. Psychiatria po Dyplomie 2017; 14: 20-23.

8. Romańczuk B, Szaflarska-Popławska A, Chełchowska M. Analysis of the concentration of vitamin $E$ in erythrocytes of patients with celiac disease. Prz Gastroenterol 2016; 11: 282-285.

9. Michałowska J, Pastusiak K, Bogdański P. Kontrowersje wokół glutenu. Forum Zaburzeń Metabolicznych 2017; 8: 103-111.

10. Walker MD, Zylberberg HM, Green P, Katz MS. Endocrine complications of celiac disease: a case report and review of the literature. Endocrine Research. https://www.tandfonline. com/doi/full/10.1080/07435800.2018.1509868 (accessed: 11.11.2018).

11. Szajewska H. Celiakia. In: Gajewski P [Ed.]. Interna Szczeklika. Wydawnictwo Medycyna Praktyczna, Kraków 2015; 975-980.

12. Kowalski M, Gąsiorowska A. Czy choroba trzewna predysponuje do rozwoju chorób nowotworowych? Gastroenterol Klin 2015; 7: 128-138.

13. Socha J, Cukrowska B. Celiakia - choroba dzieci i dorosłych. Przew Lek 2012; 15: 168-174.

14. Bączyk G, Kozłowska K, Samborski W. Health related quality of life of patients with rheumatoid arthritis - review of the literature. Forum Reumatol 2017; 3: 222-229.

15. Gastroinestial Quality of Life Index, https://eprovide. mapi-trust.org/instriments/gastrointestinal-quality-of-lifeindex\#languages (accessed: 9.10.2018).

16. Pietras-Mrozicka M. Zmiany dotychczasowego stylu życia pod wpływem leczenia dietą bezglutenową w celiakii. Przyczynek do badań. Ekonomia - Wroclaw Economic Review 2017; 23: 179-193.

17. Kowalczuk-Vasilev E, Klebaniuk R, Samolińska W, et al. Ocena wiedzy żywieniowej i realizacji założeń diety wykluczającej gluten oraz wpływu stosowanej dietoterapii na jakość życia chorych na celiakię. Hygeia Public Health 2018; 53: 91-95.

18. Korzonek M, Dziergas A. Jakość życia pacjentów z chorobą refluksową przełyku. Polski Przegląd Nauk o Zdrowiu 2014; 1: 13-19.

19. Brończyk-Puzoń A, Bieniek J, Koszowska A, et al. Jakość życia osób z celiakia, alergia i nadwrażliwością na gluten stosujących dietę bezglutenową - ocena za pomocą kwestionariusza WHOQOL-BREF. Medycyna Ogólna i Nauki o Zdrowiu 2014; 20: 241-244

20. Casellas F, Rodrigo L, Vivancos JL, et al. Factors that impact health-related quality of life in adults with celiac disease: A multicenter study. World J Gastroenterol 2008; 14: 46-52.

21. Golińska M, Duda-Grychtoł K, Klasik-Ciszewska S. Ocena stopnia wiedzy pacjentów z chorobą trzewną na temat działań profilaktycznych oraz metod leczenia. Medycyna Rodzinna 2019; 2: 60-70.

22. Lee AR, Wolf R, Contento I, et al. Coeliac disease: the association between quality of life and social support network participation. J Hum Nutr Diet 2016; 29: 383-390.

23. Alahmari TMA, Asiri AJAA, Bilali MRA, et al. Quality of life and wellbeing of patients with celiac disease in Aseer region of Saudi Arabia. Int J Med Res Prof 2018; 4: 170-174.
24. Zysk W, Głąbska D, Guzek D. Social and emotional fears and worries influencing the quality of life of female celiac disease patients following a gluten-free diet. Nutrients 2018; 10: 1414.

25. Deepak C, Berry N, Vaiphei K, et al. Quality of life in celiac disease and the effect of gluten-free diet. JGH Open 2018; 2: 124-128.

26. Casellas F, Rodrigo L, Lucendo AJ, et al. Benefit on healthrelated quality of life of adherence to gluten-free diet in adult patients with celiac disease. Rev Esp Enferm Dig 2015; 107: 196-201.

27. Limanowska P, Kubiak J, Napieraj K. Ocena opieki dietetycznej wśród osób chorych na celiakię i źródła informacji na temat diety bezglutenowej. Pielęgniarstwo i Zdrowie Publiczne 2014; 4: 351-356.

28. Jiménez Ortega Al, Martínez García RM, Quiles Blanco MJ, et al. Enfermedad celiaca y nuevas patologías relacionadas con el gluten. Nutr Hosp 2016; 33: 44-48.

29. Gładyś K, Guzek M, Adrych K, et al. Praktyczne aspekty stosowania diety bezglutenowej u osób z chorobą trzewną. Forum Medycyny Rodzinnej 2015; 9: 447-455. 